\title{
INTERVENSI PSIKOEDUKASI “ANTI MIRAS": \\ PERAN PENGUATAN PERAN TOKOH MASYARAKAT UNTUK PENCEGAHAN \\ MINUMAN KERAS
}

\section{PSYCHOEDUCATION INTERVENSION "ANTI MIRAS": THE ROLE OF COMMUNITY LEADERS IN OVERCOMING ALCOHOLIC IRREGULARITIES}

\author{
Ema Zati Baroroh \\ Wisnu Sri Hertinjung \\ Program Magister Psikologi Profesi Universitas Muhamadiah Surakarta \\ Emazati.Baroroh@gmail.com
}

\begin{abstract}
The decrease in the role of community leaders and religious leaders in overcoming alcoholic irregularities is a separate problem in a community community. The purpose of this research is generally to increase the knowledge of community and religious leaders in the prevention of misuse of alcoholic irregularities. The hypothesis of this study is that the knowledge on MIRAS on the subject would be found higher or increased after obtaining psychoeducation "Anti MIRAS". The participants of this study were community leaders and religious leaders who stated their agreement and willingness. Data were analyzed by Paired Sample of T-Test and qualitatively. Quantitative results indicate that psychoeducation intervention "Anti MIRAS" did not significantly increase participants' knowledge. However, the qualitative results found that the outcome of this intervention was able to provide a positive insight about the dangers of MIRAS and bridging community leaders to agree on 11 points of agreement. Findings, limitations and recommendations in this study will also be discussed.
\end{abstract}

Keywords: Alcohol abuse, Empowerment, Community, Psycho-education

\begin{abstract}
ABSTRAK
Menurunnya peran tokoh masyarakat (TOMAS) dan tokoh agama (TOGA) dalam mengatasi penyimpangan minuman keras (MIRAS) merupakan permasalahan tersendiri dalam suatu komunitas kemasyarakatan. Tujuan dari penelitian ini secara umum adalah untuk meningkatkan pengetahuan tokoh masyarakat dan agama dalam pencegahan penyalahgunaan MIRAS. Hipotesis dari penelitian ini adalah pengetahuan terhadap MIRAS pada subjek akan didapati lebih tinggi atau meningkat setelah mendapatkan psikoedukasi "Anti MIRAS". Peserta penelitian ini adalah tokoh masyarakat (TOMAS) dan tokoh agama (TOGA) yang menyatakan persetujun dan kesediaan. Data dianalisis dengan Paired Sample of T-Test dan secara kualitatif. Hasil kuantitatif menunjukkan bahwa bahwa intervensi psikoedukasi "Anti MIRAS" tidak signifikan meningkatkan pengetahuan peserta. Namun hasil kualitatif menemukan bahwa hasil intervensi ini mampu memberikan insight positif tentang bahaya MIRAS dan menjembatani tokoh masyarakat menyepakati 11 poin kesepakatan. Temuan, keterbatasan dan berbagai rekomendasi dalam penelitian ini juga akan didiskusikan.
\end{abstract}

Kata kunci: Penyalahgunaan minuman keras, Alkohol, Pemberdayaan, Komunitas, Psikoedukasi 
Permasalahan yang diangkat dalam penelitian kali ini berbasis pada intervensi pada sebuah komunitas. Komunitas yang digunakan berada pada Kebayanan III di Kelurahan X, Kecamatan Y, Kabupaten Klaten, Provinsi Jawa Tengah. Wilayah Kebayanan III termasuk pedukuhan yang berkepadatan penduduk sedang, dengan posisi rumah yang agak terpencar-pencar. Hampir semua rumah di pedukuhan ini masih terkesan asri, bernuansa tradisional dan hanya beberapa saja yang sudah modern beratap genteng, bertembok beton, dan berlantai keramik. Penduduk wilayah ini sebagian besar anak-anak, dan orang tua. Sebagian besar penduduk usia produktif lebih memilih merantau ke berbagai kota. Hal ini dikarenakan minimnya lapangan pekerjaan di desa dan sekitarnya. Sebagian besar penduduk yang menetap mayoritas lebih mengandalkan sektor pertanian. Kendala yang muncul adalah jika musim kemarau datang, maka pasokan air sangat menipis untuk mengairi sawah. Beberapa berprofesi sebagai pedagang dan industri rumah tangga sekitar 60 rumah.

Selanjutnya untuk lebih mengenal secara mendalam terkait kondisi desa, maka peneliti mengadakan Participatory Rural Appraissal (PRA) kepada bayan wilayah 1, 2, 3 sekaligus juga sebagai sarana menjalin kemitraan. Agenda pembahasan dalam PRA tersebut adalah mem- bahas analisis kondisi desa, kendala atau keluhan dari bidang sosial, merumuskan masalah prioritas, dan rekomendasi solusi yang diharapkan. Setelah menjalin PRA dengan para bayan maka diketahui kondisi ideal yang diharapkan oleh lancar dan meningkatnya kualitas air di desa, para pemuda dapat bertahan di desa dan turut membangun desa, kondisi desa yang aman dari penyimpangan terhadap minum-minuman keras, anak-anak usia sekolah dapat belajar dengan tekun dan menamatkan pendidikannya.

Segala potensi desa, dan kondisi ideal yang diharapkan masyarakat sayangnya dapat terhambat dengan adanya beberapa permasalahan yang diketahui melalui PRA di hampir serupa pada 3 wilayah pedukuhan tersebut. Masalah yang paling ringan yang dibantu diurutkan oleh peneliti adalah 3 pasangan yang bercerai. Kedua, anak-anak SD sampai SMP yang sudah diberikan HP. Selain itu juga permasalahan yang ketiga adalah posyandu lansia yang macet sudah hampir 1 tahunan, padahal di wilayah Kelurahan $\mathrm{X}$ terdapat banyak usia lansia. Keempat, terdapat beberapa pelajar usia sekolah mengalami hamil di luar nikah. Akibatnya, rata-rata di antara mereka putus sekolah dan menikah pada usia muda. Permasalahan kelima yang dikeluhkan adalah anak usia SMP yang sulit belajar. Mereka berkata pada orang tua ingin 
belajar kelompok tapi ternyata setelah diselidiki mereka justru main PS hingga larut malam. Masalah yang terakhir yang keenam yang dikeluhkan adalah masalah penyalahgunaan minuman keras (MIRAS).

Berdasarkan rekomendasi dari Bayan 3 masalah yang dianggap penting bagi masayarakat adalah mengenai penyalahgunaan MIRAS. Beliau juga meminta disediakan waktu khusus untuk diberikan penyuluhan MIRAS di wilayahnya. Beliau mengeluhkan jika ada hajatan misalnya pernikahan, di wilayahnya hampir selalu ada minuman keras dan bermain gitar hingga larut malam. Beliau juga menuturkan masalah akan semakin timbul dengan pulangnya para perantau ke desa. Mereka biasanya mengajak dan mentraktir pemuda desa untuk minum minuman keras. Hal tersebut menunjukkan bahwa penyalahgunaan MIRAS di desa telah membudaya dan kurangnya pengetahuan tentang bahaya MIRAS sehingga masyarakat yang menetap di desa mudah terbawa arus perubahan.

Data penunjang yang didapatkan dari Kepolisian Daerah Klaten (Ilham, 2014) mengungkapkan bahwa salah satu daerah yang memiliki angka kerawanan yang cukup tinggi dalam penyalahgunaan minuman keras adalah di Kecamatan Cawas. Di daerah tersebut terdapat penindakan tindak pidana ringan berupa 19 kasus penyalahgunaan MIRAS dengan barang bukti penyitaan vodka sebanyak 22 botol, ciu 31 liter, anggur merah dan putih sebanyak 44 botol. Berbagai temuan perilaku penyalahgunaan MIRAS tersebut jika dibiarkan begitu saja maka akan bertambah parah dan meluas kepada permasalahan-permasalahan lain. Selain itu didapati bahwa pengetahuan Tokoh Mayarakat (TOMAS) dan Tokoh Agama (TOGA) pada Kebayanan 3 terhadap MIRAS juga perlu untuk mendapat perhatian khusus. Hal ini dijabarkan dengan tabel di bawah ini

Tabel 1. Tingkat Pengetahuan TOMAS dan TOGA Kebayanan 3 Terhadap Bahaya MIRAS

\begin{tabular}{|c|c|c|c|}
\hline No & Aspek Yang Dievaluasi & $\begin{array}{l}\text { Kriteria } \\
\text { Evaluasi }\end{array}$ & Jumlah $(\%)$ \\
\hline 1 & Persepsi keliru dampak MIRAS bagi kesehatan tubuh & Benar & 33,3 \\
\hline 2 & $\begin{array}{l}\text { Persepsi keliru MIRAS tidak menyebabkan } \\
\text { pelanggaran pidana }\end{array}$ & Benar & 19,00 \\
\hline 3 & Persepsi keliru dewasa jika MIRAS & Benar & 28,6 \\
\hline 4 & $\begin{array}{l}\text { Persepsi keliru MIRAS dapat melepaskan } \\
\text { permasalahan hidup }\end{array}$ & Benar & 14,3 \\
\hline 5 & Kontrol sosial berperan dalam timbulnya MIRAS & Salah & 14,3 \\
\hline 6 & Definisi kecanduan & Salah & 23,8 \\
\hline 7 & Menghadapi persoalan hidup & Salah & 14,3 \\
\hline 8 & Definisi alkoholisme & Salah & 23,8 \\
\hline
\end{tabular}


Selain itu berdasarkan pengolahan data kuantitatif masih didapati beberapa persentase aspek tingkat pengetahuan yang dirasa cukup rendah. Hal ini dibuktikan masih ada $27 \%$ TOMAS dan TOGA yang belum mengetahui dampak yang timbulnya perilaku minum MIRAS, dan $29 \%$ ciri-ciri orang ketagihan alkohol. Hal ini bertolak belakang dengan fungsi TOMAS dan TOGA yang harus melindungi dan mengingatkan warganya jika berbuat kesalahan. Hal tersebut seharusnya dapat ditingkatkan karena jika dibiarkan begitu saja akan membawa problematika yang sangat merugikan, yaitu akan mempengaruhi sikap dan perilaku yang condong pada penyalahgunaan MIRAS.

Hal ini diperkuat oleh penelitian yang dilakukan oleh Sulawesiyanto (Sriyani 2008) yang menyatakan bahwa minuman keras memberikan pengaruh besar terhadap kenakalan remaja. Dari 20 sampel remaja yang mengkonsumsi minuman beralkohol, $80 \%$ di antaranya sampel mengaku pernah melakukan kenakalan remaja. Bentuk kenakalan remaja yang pernah dilakukan di antaranya kejahatan terhadap kesusilaan, pencurian, penipuan, bahkan penganiayaan. Seseorang yang mengkonsumsi minuman keras, timbul keberanian untuk melakukan tindakan negatif. Seperti perkelahian, dimana secara normal mereka tidak berani melakukannya. Minuman keras ini juga menyebabkan ketergantungan atau ketagihan pada diri mereka, sehingga mereka melakukan berbagai upaya untuk mendapatkannya, bahkan dengan melakukan tindak kejahatan pencurian. Minuman keras juga menyebabkan terganggunya otak sehingga membuat hilang rasa malu, dan mereka juga menjadi mudah tersinggung serta cepat marah.

Jika TOMAS dan TOGA tidak terlibat aktif menjaga masyarakat khususnya pemuda di Kebayanan ini yang perlahan akan dirusak akibat pengaruh minuman keras maka dampak awalnya bisa jadi tidak dirasakan, namun lambat laun akan dirasakan bahkan dapat menjadi fenomena di kemudian hari. Dengan demikian, maka kami memandang penting adanya sebuah pencegahan untuk meningkatkan peran TOGA dan TOMAS dalam melindungi warga dari perilaku minum-minuman keras. Hal ini diperkuat pernyataan Green (Prisaria, 2012) dikatakan bahwa tindakan yang berdaya guna dan berhasil guna bila melalui tindakan pencegahan dibanding tindakan yang lain, yaitu pengobatan dan rehabilitasi. Atas dasar pertimbangan-pertimbangan di atas maka peneliti tertarik untuk melakukan usaha preventif kasus perilaku minuman keras di wilayah kebayan 3 dari sisi penguatan peran TOMAS dan TOGA.

Beberapa penelitian telah menunjukkan efektivitas berbagai terapi dalam pencegahan miras diantaranya program kecakapan hidup dan proses belajar 
(Santosa, Atmodiwirjo, Soetikno, 2012; Supraptiningsih,2004). Upaya lain yang dapat dilakukan melalui pemberian psikoedukasi berdasarkan penelitian Ilham (2014). Hasil dari studi ini menunjukkan bahwa ada perbedaan pengetahuan tentang minuman keras pada warga yang mengikuti pelatihan dan tidak mengikuti pelatihan.

Penelitian ini merujuk pada penelitian Ilham (2014) dengan beberapa penyesuaian dan perubahan. Hal ini dikarenakan kemiripan karakteristik subjek. Dengan demikian pada penelitian ini, tindakan pencegahan yang akan dilakukan berupa pemberian intervensi psikoedukasi kepada tokoh masyarakat dan tokoh agama di Kebayanan 3. Tujuan umum dari penelitian ini adalah untuk meningkatkan pengetahuan tokoh masyarakat dan agama dalam pencegahan penyalahgunaan MIRAS. Sementara tujuan khusus dari penelitian ini adalah Pertama mengetahui hal-hal yang berkaitan dengan penyebab, faktor, dampak, dari penyimpangan perilaku minum-minuman keras warga wilayah Kebayanan 3. Kedua, melakukan tindakan preventif berupa pemberian program psikoedukasi "Anti MIRAS" sebagai sarana pencegahan terhadap pengaruh penyalahgunaan MIRAS. Ketiga membantu TOGA dan TOMAS untuk merumuskan kesepakatan bersama untuk memberantas miras di Kebayanan 3. Oleh sebab itu rumusan masalah sebagai pertanyaan dalam penelitian ini adalah "Bagaimana pengaruh intervensi psikoedukasi MIRAS terhadap peningkatan pengetahuan TOMAS dan TOGA ?"

Hipotesis dapat diartikan penjelasan alternatif terhadap suatu fenomeneon. Selain itu di tingkat teoritis hipotesis dapat menawarkan alasan ("mengapa") untuk bagaimana variabel-variabel tertentu saling berhubungan (Shaughessy, Zechmeister, \& Zechmeister, 2007). Dengan demikian hipotesis yang diajukan dalam penelitian ini adalah pengetahuan terhadap MIRAS pada subjek akan didapati lebih tinggi atau meningkat setelah mendapatkan psikoedukasi "Anti MIRAS".

\section{METODE PENELITIAN}

\section{Desain Penelitian}

Penelitian ini merupakan penelitian eksperimen. Penelitian eksperimen ini menggunakan desain One group pretest posttest design, yaitu eksperimen yang dilaksanakan pada satu kelompok saja tanpa kelompok pembanding. Hal ini dilakukan karena terbatasnya waktu yang diestimasikan peneliti. 


\section{Non R Opre X Opost}

Gambar 1. One group pretest posttest design

Keterangan :

Non $\mathrm{R}$ : Tidak adanya randomisasi pada penelitian

Opre : Pengukuran sebelum perlakuan

Opost : Pengukuran setelah perlakuan

X : Psikoedukasi "Anti MIRAS"

\section{Subjek Penelitian}

Teknik atau pemilihan subjek dilakukan dengan Purpossive sampling, salah satu teknik yang termasuk dalam nonrandom sampling (Latipun, 2002). Alasan pemilihan teknik ini karena teknik ini memungkinkan pemilihan partisipan sesuai dengan kriteria yang dikehendaki oleh peneliti. Pemilihan sampel memiliki kriteria sebagai berikut, yaitu (1) Berada pada lingkup Kebayanan 3, (2) Merupakan TOMAS, TOGA, dan atau tokoh pemuda, (3) Mendapat rekomendasi dari bayan 3 untuk hadir, dan (4) Menyatakan kese-diaan berpartisipasi.

\section{Metode Pengumpulan data}

Alat ukur dalam penelitian menggunakan pengukuran secara kualitatif dan kuantitatif. Mengkombinasikan kedua metode ini sangat bermanfaat untuk memperoleh data yang lebih menyeluruh, dibanding hanya mengunakan 1 metode. Pelaksanaan dalam penelitian, pada saat intervensi diberikan kuesioner pengetahuan terhadap miras sebelum dan sesudah intervensi. Kuesioner ini menggunakan kuesioner dari Ilham (2014). Selanjutnya pada saat intervensi dilakukan observasi. Selain itu data observasi dapat berupa interaksi dalam organisasi (kelompok) atau pengalaman anggota dalam suatu kelompok (Raco, 2013). Dengan demikian observasi ini berupa pengamatan langsung terhadap hal-hal yang terjadi pada saat intervensi, dinamika kelompok. Adanya observasi menambah kekayaan data mengenai proses intervensi, keaktifan peserta, dan proses interaksi saling mempengaruhi antar anggota kelompok.

\section{Prosedur Intervensi}

Variabel dalam penelitian ini adalah intervensi psikoedukasi "Anti MIRAS" dan penyalah gunaan MIRAS. Perlakuan yang akan diberikan pada peserta berupa pemberian Intervensi Psikoedukasi "Anti MIRAS". Kegiatan intervensi tersebut melibat kan 1 orang mc untuk memandu 
pelaksanaan intervensi ini, pihak puskesmas sebagai pemateri dari sisi kesehatan, dan 1 pemateri dari sisi psikologi. Prinsip intervensi ini lebih mengacu pengunaan metode ceramah, dan diskusi. Durasi pada pelatihan kali ini kurang lebih selama 2,5 jam, berjumlah 1 kali perlakuan degan 5 sesi.

Lebih rinci lagi intervensi ini memberikan kesempatan pemaparan psikoedukasi bahaya miras dari sisi kesehatan dan dari sisi psikologi. Sesi selanjutnya merupakan tanya jawab serta adanya forum diskusi untuk memberi kesempatan kepada tokoh agama dan tokoh masyarakat untuk menyempaikan gagasan untuk upaya pencegahan miras. Selanjutnya sesi ditutup dengan deklarasi "Selamatkan Kampungku Dari MIRAS" merupakan poin-poin yang telah disepakati sebagai upaya pencegahan miras.

\section{Teknik Analisis Data}

Arikunto (Idrus, 2009) menyebutkan tiga langkah yaitu persiapan, tabulasi, dan penerapan data sesuai dengan pendekatan penelitian. Selain itu dalam penelitian ini pengolahan data dilakukan dengan kuantitatif dan kualitatif. Pengolahan data kuantitatif peneliti menggunakan metode paired sample of t-test dengan menggunakan SPSS 17.0 for windows. Sedangkan pengolahan data kualitatif dilakukan observasi selama kegiatan intervensi berlangsung dan wawancara follow up pasca intervensi.

\section{HASIL PENELITIAN}

\section{Hasil Kualitatif}

Pada saat intervensi. Jika dilihat secara kualitatif maka penyuluhan ini terbilang cukup dinamis. Hasil ini dikarenakan pada saat diskusi para tokoh masyarakat tidak segan-segan untuk mengeluarkan argumennya masing-masing, sehingga terjadilah proses saling memberi masukan dan bertukar pikiran. Selain itu penyuluhan tersebut tidak hanya berhenti pada sisi edukasi saja namun peneliti bersama tokoh masyarakat mampu membentuk 11 poin kesepakatan. Pada kesempatan penyuluhan tersebut sekaligus juga dideklarasikan "Selamatkan Kampungku Dari MIRAS", sebuah gerakan yang menjalin kemitraan bersama tokoh masyarakat dengan ditanda tangani oleh bayan wilayah 3, perwakilan tokoh masyarakat, perwakilan tokoh agama, perwakilan tokoh pemuda, dan peneliti sebagai perwakilan pihak penyelengara. Kesebelas poin yang telah disepakati tersebut yaitu (1) Mengusulkan untuk warung disekitar kampung diperiksa agar tidak menjual MIRAS. (2) Jangan meminum-minuman di depan umum atau pada saat hajatan. (3) Peningkatan kegiatan keagaamaan dan memfasilitasi untuk membuat pengajian pemuda pemudi. (4) Mencegah dan mengurangi MIRAS mulai 
dari para tokoh masyarakat terlebih dahulu. (5) Hendaknya saat hajatan ada peraturan tentang larangan MIRAS. Dalam bentuk tidak boleh minum-minuman keras mulai pada saat mindodareni. (6) Perlu peraturan dan adanya sanksi jika melanggar. (7) Saat musyawarah panitia hajatan, panitia membuat peraturan tentang larangan MIRAS dan tidak ada lagi yang menyediakan tradisi MIRAS. (8) Menambah kegiatan positif bagi pemuda misalnya berolah raga. (9) Hendaknya orang tua mengajarkan anaknya untuk solat di masjid. (10) mengurangi begadang untuk mencegah MIRAS. (11) Orang tua hendaknya memberikan teladan yang baik.
Follow up Intervensi. Berdasarkan wawancara dengan bayan 3 pada 1 bulan pasca perlakuan, yang bersangkutan meyepakati untuk terus melanjutkan program dengan menyampaikan melalui acara-acara warga, berupa arisan ataupun rapat rutin. Beliau juga menyampaikan bahwa saat ini kebijakan tersebut sudah menyebar secara informal ke warga dari mulut ke mulut. Beliau juga mengatakan melalui program penelitian yang dilakukan peneliti, ia memiliki insight gagasan untuk melarang warga meminum minuman keras di jalan desa khususnya pertigaan.

\section{Hasil Kuantitatif}

Tabel 3. Analisa Kuantitatif

\begin{tabular}{cccccc}
\hline Variabel Penelitian & Pre & Mean & $\mathrm{c}$ paired sample of t-test \\
& 0.8032 & 0,7683 & $1.471(20)$ & $0.075^{* *}$ \\
\hline $\begin{array}{c}\text { Pengetahuan_Prettest } \\
\text { Pengetahuan_Posttest }\end{array}$ & & & & \\
\hline$* * p>0.05$ & & &
\end{tabular}

Pengaruh intervensi ini secara kuantitatif dilihat dari data prates dan pascates menggunakan skala Ilham (2014) mengenai pengetahuan terhadap MIRAS. Tabel 3 di atas merupakan hasil analisa uji Paired Sample of T-Test, memperlihatkan tidak adanya variasi pengetahuan pada level 0.05 sebelum dan setelah mendapatkan intervensi psikoedukasi. Hal ini menunjukkan bahwa intervensi psikoedukasi "Anti MIRAS" tidak signifikan meningkatkan pengetahuan peserta $(p>$ 0.05 , one tailed $p=0.075$ ).

\section{PEMBAHASAN}

Tujuan khusus pertama dari penelitian ini adalah mengetahui hal-hal yang 
berkaitan dengan penyebab, faktor, dampak, dari penyimpangan perilaku minumminuman keras warga wilayah Kebayanan 3. Tujuan ini telah dicapai dengan mengadakan asesmen sebelum melaksanakan intervensi. Hasil integrasi data diperoleh dari asesmen dengan metode interview kepada 6 tokoh masyarakat. Mayoritas warga ingin wilayah desanya terbebas dari miras. Usia yang terlibat penyalahgunaan miras tergolong beragam, mayoritas pada usia pemuda umur 18-25 tahun. Miras yang dikonsumsi sejenis ciu. Jika dilihat secara kasat mata memang belum ada dampak yang luas, namun cukup meresahkan warga yang lewat. Hampir seluruh responden sepakat penyebab utama dari penyalahgunaan miras adalah karena adanya pengaruh orang kota yang pulang kampung ke desa dan memberikan dana untuk mentraktir teman-temannya. Namun untuk waktu biasanya meminum-minuman keras termasuk tidak menentu. Mayoritas saat orang kota pulang ke desa, dan saat ada hajatan nikahan yng paling banyak pada bulan syawal. Kegiatan tersebut biasa dilakukan selepas isya. Selama ini para tokoh tersebut tidak berani menegur, dan biasanya melalui upaya keagamaan, namun saat ini sudah mulai mengalami penurunan. Pada akhirnya hampir semua tokoh yang diwawancarai sepakat dengan perlunya upaya pencegahan berupa penyuluhan.
Tujuan kedua penelitian adalah melakukan tindakan preventif berupa pemberian program psikoedukasi "Anti MIRAS" sebagai sarana pencegahan terhadap pengaruh penyalahgunaan MIRAS. Hal ini juga berhasil dipenuhi dengan terlaksananya program penyuluhan atau psikoedukasi. Pelaksanaan psikoedukasi tersebut melibatkan kerjasama juga dengan pihak puskesmas setempat yang membawakan bahaya miras dari sisi kesehatan, serta pihak Magister Psikologi Profesi UMS yang membawakan materi miras dari sisi psikologis dan social. Terlaksananya penyuluhan ini sekaligus juga menjawab hipotesis yang diajukan, berdasarkan hipotesis tersebut sayangnya psikoedukasi ini diketahui kurang membawa pengaruh yang signifikan (lihat tabel 3 hasil kuantitatif).

Tujuan ketiga penelitian adalah membantu TOGA dan TOMAS untuk merumuskan kesepakatan bersama untuk memberantas miras di Kebayanan 3. Hal ini juga terlaksana pada saat intervensi. Jika dilihat secara kualitatif, maka penyuluhan ini cukup membuahkan hasil dan terbilang dinamis. Hasil ini dikarenakan pada saat diskusi para tokoh masyarakat tidak segan-segan untuk mengeluarkan argument, terjadi juga proses saling memberi masukan dan bertukarfikiran. Diskusi tersebut menghasilkan kesebelas poin kesepakatan penanganan miras di kebayanan 3 (lihat 
hasil kualitatif). Kesepakatan tersebut kemudian dibacakan bersama-sama sekaligus sebagai ikrar deklarasi "Selamatkan Kampungku Dari MIRAS". Hal ini dimaksudkan dengan membangun kesepakatan bersama terciptalah kebersamaan dan peran kolaboratif yang terlahir dari daya upaya masyarakat sendiri.

Pemberdayaan masyarakat diartikan suatu strategi yang digunakan dalam pembangunan masyarakat sebagai upaya untuk mewujudkan kemampuan dan kemandirian dalam kehidupan bermasyarakat, berbangsa dan bernegara (Peraturan menteri dalam negeri Nomor 7 tahun 2007). Dengan demikian penelitian ini termasuk field study yang lebih menekankan pada metode partisipatoris dan upaya pemberdayaan masyarkat. Pemberdayaan masyarakat dilihat dari upaya peneliti untuk membangun kemitraan dan partisipasi dari tokoh masyarakat setempat yang berperan sebagai stake holder. Misalnya sejak awal peneliti menawarkan kerjasama dan berupaya bersama masyarakat untuk mencari solusi terhadap masalah sosial yang dialami masyarakat. Peneliti juga mengadakan Participatory Rural Appraissal (PRA) bersama perwakilan masyarakat berdialog merumuskan permasalahan yang hendak diangkat bersama. Serta beberapa upaya kolaborasi lain, termasuk kolaborasi peneliti bersama puskesmas setempat. Dengan kata lain penelitian ini lahir dari masyarakat dan kembali kepada masyakarat. Hal ini sesuai dengan pendapat Mikkelsen (1999) bahwa partisipasi bisa saja menjadi sebuah slogan tanpa makna yang nyatata. Partisipasi yang sebenarnya satang dari inisiatif masyarakat itu sendiri, merupakan tujuan dalam proses demokrasi.

Satu komponen penting yang tidak dapat diabaikan dalam pemberdayaan masyarakat adalah peran penting dari stake holder yang dalam hal ini meluputi TOMAS, TOGA, dan tokoh pemuda. Disadari atau tidak stake holder sendiri merupakan pengerak utama atau agen of change dalam suatu komunitas sosial. Hal ini juga senada dengan pendapat Waluyo (2010) menyatakan bahwa agen perubahan (agent of change) adalah orang yang bertugas mempengaruhi orang atau masyarakat agar mau menerima inovasi sesuai dengan tujuan yang diinginkan oleh pengusaha pembaharuan (change agency). Namun hal ini berkebalikan dengan realita yang didiapati di lapangan. Seperti yang telah dipaparkan dalam beberapa poin sebelumnya, dari hasil asesmen didapati bahwa TOMAS dan TOGA kurang berfungsi optimal dalam mengatasi permasalahan MIRAS di wilayah mereka. Padahal perkembangan zaman terus saja berputar, dan kebayanan 3 memiliki kerentanan terhadap penyalahgunaan miras. Peneliti kemudian berdiskusi dengan stake holder setempat, sehingga merumuskan gagasan bahwa 
perlu adanya upaya mengembalikan peran TOGA dan TOMAS untuk menjadi garda terdepan dalam penanggulangan MIRAS. Oleh sebab itu lahirlah upaya psikoedukasi sekaligus menginisiasi kegiatan urun rembuk ide dan gagasan untuk membuat suatu peraturan atau kesepakatan untuk mencegah penyalahgunaan MIRAS. Tidak sedikit keunggulan mengunakan pemberdayaan masyarakat dalam pemberantasan miras. Salah satu diantaranya dapat menginisiasi masyarakat untuk mendapatkan insight atau gagasan baru untuk menjamin keberlangsungan program dalam jangka panjang (sustainability). Hal ini juga dapat dilihat dengan capaian dalam penelitian ini, walaupun tidak banyak menjamin sustainability program namun setidaknya tokoh masyarat mulai memiliki gagasan dan tergerak untuk melindungi kampongnya dari miras (lihat follow up intervensi). Namun penelitian ini tidak terlepas dari kelemahan materi yang diberikan pada sarana intervensi kurang dalam, dan kurang mampu menjangkau kebutuhan tokoh masyarakat. Selain itu dari sesi penyelengaraan terbatasnya waktu menjadi kendala, karena pelaksanaan psikoeduksi dilaksanakan pada malam hari.

\section{SIMPULAN DAN SARAN}

\section{Simpulan}

Berdasarkan hasil pelaksanaan yang sudah dilakukan maka dapat diambil kesimpulan. Pertama: Permasalahan yang terjadi Wilayah Kebayanan 3, Kelurahan $X$, Kecamatan $Y$ adalah resiko penyalahgunaan MIRAS. Menurut keterangan Bayan di wilayah tersebut, jika adanya hajatan pernikahan hampir selalu ada minuman keras dan bermain gitar hingga larut malam. Beliau juga menuturkan masalah akan semakin timbul dengan pulangnya para perantau ke desa. Mereka biasanya mengajak dan mentraktir pemuda desa untuk minum minuman keras.

Kedua: Berdasarkan hasil asesmen didapati mayoritas warga ingin wilayah desanya terbebas dari MIRAS. Usia yang terlibat penyalahgunaan MIRAS tergolong beragam ada yang remaja dan dewasa. Jika dilihat kasat mata memang belum ada dampak yang luas, namun cukup meresahkan warga yang lewat. Hampir seluruh responden sepakat penyebab utama dari penyalahgunaan MIRAS karena adanya pengaruh orang kota yang pulang kampung ke desa dan memberikan dana untuk mentraktir teman-temannya. Namun untuk kapan waktu biasanya meminumminuman keras termasuk jarang. Mayoritas saat orang kota pulang ke desa, dan saat ada hajatan nikahan. Kegiatan tersebut biasa dilakukan selempas isya. Selama ini para tokoh tersebut tidak berani menegur, dan biasanya lewat 
agama namun sudah mulai mengalami penurunan. Pada akhirnya hampir semua tokoh yang diwawancarai sepakat dengan perlunya upaya pencegahan berupa penyuluhan.

Ketiga: Setelah dilakukan intervensi hasil analisa kuantitatif menunjukkan bahwa intervensi psikoedukasi tidak signifikan meningkatkan pengetahuan peserta $(p>0.05, p=0.075)$. Walau intervensi ini secara kuantitatif kurang menunjukkan hasil yang mengembirakan. Namun secara kualitatif peneliti mampu untuk membantu para tokoh masyarakat untuk mencapai 11 poin kesepakatan pencegahan MIRAS. Selain itu setelah intervensi tokoh setempat juga memiliki gagasan untuk melakukan pelarangan warga untuk minum minuman keras di pertigaan jalan.

\section{Saran}

Berdasarkan dari hasil intervensi berbasis komunitas yang telah dilakukan maka adapun saran yang dapat diberikan untuk lebih mengoptimalkan hasil yang didapat adalah sebagai berikut. Pertama: Peserta Intervensi (Tokoh Masyarakat, Tokoh Agama, Dan Tokoh Pemuda). Para tokoh masyarakat, tokoh agama dan tokoh pemuda hendaknya mampu untuk melaksanakan kesepakatan yang telah dirumuskan bersama dengan memulai mengghentikan konsumsi miras dari diri mereka sendiri. Selain itu penting untuk menindak lanjuti sebelas butir kesepakatan tersebut ke dalam rancangan-rancangan program yang lebih kogrit. Para tokoh juga mampu untuk menyosialisasikan kesepakatan tersebut kepada warga masyarakat di seluruh wilayah kebayanan III agar kebijakan tersebut dapat terealisasi penuh di masyarakat. Kepada tokoh masyarakat secara umum hendaknya mampu untuk menjadi benteng terdepan dalam upaya menjaga masyarakat dari penyalahgunaan miras.

Kedua: Masyarakat. Hendaknya masyarakat kebayanan wilayah 3 kelurahan X mampu untuk menaati dan mampu membantu para tokoh masyarakat dalam pengaplikasian butir kesepakatan upaya pencegahan "Selamatkan Kampungku Dari MIRAS" di masyarakat. Selain itu bagi masyarakat umum, mampu untuk lebih proaktif dalam memantau kondisi lingkungannya dan menegur jika ada salah oknum warga yang terlibat dalam penyalahgunaan miras.

Ketiga: Birokrasi Kelurahan. Hendaknya para aparatur kelurahan X mampu untuk secara menyeluruh mangadakan kegiatan psikoedukasi tentang bahaya miras, agar terjadi sinergisitasnya di seluruh wilayah kelurahan terkait dengan langkah pencegahan terhadap miras 


\section{DAFTAR PUSTAKA}

Santosa, E., T., Atmodiwirjo, E., T., Soetikno, N. (2012). Efektifitas kecakapan hidup sebagai pencegahan penyalahgunaan tembakau, alcohol, mariyuana (studi pada siswi/l SMPN X). Provitae Jurnal Psikologi Pendidikan, 5, (1), 73-92

Agung.(2015). Perilaku sosial pengguna minuman keras di kelurahan sungai dama kota Samarinda. Jurnal Sosiatri Sosiologi, 3 (1), 60 - 70

Awang, S., A, Widayanti, T.W., Himmah B, Astuti, A, Septiana M. S, Solehudin, \& Novenanto, A. (2008). Panduan pemberdayaan lembaga masyarakat desa hutan (LMDH). Jogjakarta: Pusat Kajian Hutan Rakyat

Cholisin. (2011). Pemberdayaan masyarakat. Disampaikan Pada Gladi Manajemen Pemerintahan Desa Bagi Kepala Bagian/Kepala Urusan Hasil Pengisian Tahun 2011 Di Lingkungan Kabupaten Sleman, 1920 Desember 2011

Idrus, M. (2009). Metode penelitian ilmuan sosial. Jakarta: Erlangga

Ilham, T.W. (2014). Psikoedukasi bahaya ketagihan MIRAS pada remaja di Desa Genengan Kelurahan Tam- bong Wetan Kecamatan Kalikotes. Laporan Praktek Kerja Profesi Psikologi Kasus Komunitas. (tidak diterbitkan). Surakarta: Universitas Muhammadiyah Surakarta

Latipun. (2002). Psikologi Eksperimen. Malang: UMM Press

Muslim,A. (2007). Pendekatan prespektif dalam pemberdayaan masyarakat. Jurnal Aplikasi IImu-IImu Agama, 8 (2), $89-103$

Mikkelsen, B. (1999). Metode penelitian partisipatoris dan upaya-upaya pemberdayaan: Sebuah buku pegangan bagi para praktisi lapangan. Jakarta: Buku Obor

Nevid, J.S., Rathus, S.A, \& Greene, B. (2005). Psikologi abnormal jilid 2. Jakarta: Erlangga

Nugroho, D. J. (2012). Pemberdayaan pemuda melalui proses rehabilitasi korban penyalahgunaan narkoba di lembaga panti sosial pamardi putra (PSPP) Yogyakarta. Skripsi (tidak diterbitkan). Universitas Negri Yogyakarya

Pratama, D. V. (2013). Perilaku remaja penggunaan minuman keras di desa jatigono Kecamatan Kunir Kabupaten lumajang. Skripsi (tidak diter- 
bitkan). Universitas Airlangga: Surabaya (tidak diterbitkan)

Permatasari, D. (2013). Perbedaan pengaruh pendidikan kesehatan menggunakan leafleat dengan audiovisual terhadap tingkat pengetahuan remaja tentang bahaya minuman keras di desa Wates Simo Boyolali. Skripsi (tidak diterbitkan). Universitas Muhammadiyah Surakarta (tidak diterbitkan)

Prisaria, N. (2012). Hubungan pengetahuan dan lingkungan sosial terhadap tindakan pencegahan penyalahgunaan napza pada siswa SMA negeri 1 Jepara. Skripsi. (tidak diterbitkan). Semarang: Universitas Diponegoro

Raco, J., R. (2013). Metode Penelitian Kualitatif: Jenis Karakteristik dan Keunggulannya. Jakarta: Grasindo

Shaughessy, J., J., Zechmeister, E., B., \& Zechmeister, J., S. (2007). Metode penelitian dalam psikologi edisi 7. Yogyakarta: Pustaka Pelajar
Sriyani. (2008). Tinjauan perilaku minum minuman beralkohol dan gangguan kondisi kesehatan pada pemuda di desa Kiringan Boyolali. Skripsi. (tidak diterbitkan). Surakarta: Universitas Muhamadiyah Surakarta.

Supraptiningsih, E. (2004). Upaya intervensi pencegahan dan penanggulangan penyalahgunaan NAZA (narkotik, alcohol, dan zat adiktif) pada remaja melalui proses belajar. Mimbar, XX (2), 164-178

Suranata, K. (2015). Pengembangan model konseling logo untuk mencegah penyalahgunaan narkoba, psikotropika dan zat adiktif lainnya pada para siswa di Bali. Jurnal Pendidkan Indonesia: Universitas Ganesha (diakses pada tanggal 30 Juni 2015)

www. Forda_mof.or.ig. Diunduh pada tanggal 23 Juni 2015

www Ik.pom.go.id- Bahaya - MIRAS. Diunduh pada tanggal 26 juni 2015

www.kemendagri.co.id. Diunduh pada tanggal 30 Oktober 2015 